\title{
Students' Perception toward the Use of Google Site as English Academic Diary
}

\author{
Dian Puspita ${ }^{1}$, Sandi Nuansa ${ }^{2}$, Annisaa Toya Mentari ${ }^{3}$ \\ ${ }^{1,2,3)}$ Program Studi Sastra Inggris, Fakultas Sastra dan Ilmu Pendidikan, Universitas Teknokrat Indonesia \\ e-mail:dian.puspita@teknokrat.ac.id
}

\begin{abstract}
As technology has been developing, it influences all aspect of human's life, including learning process in education. There are a lot of online platforms that can be used to facilitate learning and enhance students' understanding on the subject. One community service activity was done to make the innovative use of technology, Google Site, as Academic Diary for English subject. This paper was aimed to describe students' perception toward the use of Google Site as online Academic Diary. Twenty students participated in this activity, and a questionnaire was distributed to find out their perception toward the use of Google Site. The result showed that most students received the positive perception, especially at Perception of Digital Technology and the use of Google Site.
\end{abstract}

Keywords: Academic Diary, English, Google Site, Perception

\section{INTRODUCTION}

Along with the times and increasingly advanced technology always demands changes where humans must be able to adapt to changes in various sectors, especially in the world of education. One of the technologies having a major influence in the world of teaching and learning is the Internet where this technology is able to provide education access anytime and anywhere. Moreover, during the Covid-19 pandemic since early 2020 until now, the face-to-face learning process must be forced to change according to the situation to become online learning (Susanthi, 2020; Wiramarta, 2021). Therefore, internet-based learning is an alternative solution for the current problem. In the context of online learning, there are problems and challenges that students face due to restrictions on access to signals, it is difficult for them to participate in online activities, and they still rely on teaching materials provided by teachers (Puspita et al., 2021; Setyawan, 2019). In addition, the students also do not understand very well how to classify and organize teaching materials or sources of information that they get both from school and from the internet. Therefore, it is very important for students to have knowledge of technology to increase their learning motivation (Ulfa \& Puspaningtyas, 2020). In this case, an innovation in the learning process is needed where information sources are integrated with the students' personal academic diary.

Nowadays, with the technology has been improving, there are a lot of media and online platforms that can be used either by students or teachers. One of them is Google Site. Google Site is a Google service that allows users to easily and freely create a website equipped with various functions, such as adding images, videos, links, and other documents (Arumdani et al., 2018; Djusar et al., 2021; Taufik et al., 2018). By using Google Site, students can creatively create their own website as academic diary, where they can store all the teaching materials they have obtained from teachers and the Internet. In this site, students can store, sort, and organize teaching materials, learning resources, assignments, exam questions from each subject, especially English subject. English is one of the subjects that is quite difficult and more challenging to learn in online learning because students are required to practice and master four basic competencies such as speaking, writing, reading, and listening (Mandasari \& Aminatun, 2019; Puspita \& Amelia, 2020; Wiramarta, 2021). In addition, because English is not a native language, students are not motivated to learn, and some people still think that it is difficult to master English (Susanthi, 2020). Therefore, in today's online learning, English teachers as learning facilitators need to be more creative and innovative in providing materials to increase students' low learning motivation.

For the background mentioned earlier, a training was conducted to initiate helping students improve their learning activity by introducing the use of Google Site as English Academic 
Diary. A series of activity was done and the students' perception toward the use of Google Site was found out. It was done as evaluation process (Puspaningtyas \& Dewi, 2020). Therefore, this paper is aimed to elaborate the training process and students' perception toward the use of Google Site as online Academic Diary for English subject at SMA Islam Global Surya, Bandar Lampung, Lampung Province.

\section{METHOD}

This training to use Google Site as online Academic Diary was conducted in one Senior High School in Bandarlampung, namely SMA Islam Global Surya. The trainer team consisted of English literature lecturer and students. This team was responsible to give introduction of Google Site and to give the training on how to create and use Google Site as online Academic Diary. The method used in this training was qualitative measurements using the questionnaires to determine students' perception toward the use of the Google Site as online Academic Diary. The stages of this training flow starting from preparation, data collection, and evaluation are shown in Figure 1.

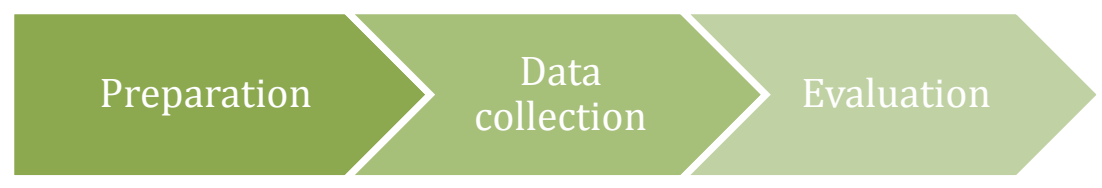

Figure 1. Training stages

The first stage is preparation. At this stage, the team was doing the research on the partner's need and seeking the collaboration opportunity to conduct the training. In addition, the preparation of training materials and questionnaire preparation were done. After an understanding was achieved, the team started the training and collected the data. In the second stage, data was collected in the form of initial test results from 20 students of Global Surya Islamic High School as training participants. Furthermore, training on the use of the Google Site was carried out in four meetings, conducted online and offline. Furthermore, at the last meeting, data were taken again through a final test and a questionnaire on student responses to the implementation of the training. This was conducted as evaluation process. The following are the stages of implementing the training and their respective indicators of achievement are listed in Table 1.

Tabel 1. English Academic Diary Training Schedule

\begin{tabular}{|c|c|c|}
\hline No. & Acitivity & Indicator \\
\hline 1 & $\begin{array}{ll}\checkmark & \text { Pre-test } \\
\checkmark & \text { Creating Google Site }\end{array}$ & $\begin{array}{ll}\checkmark & \text { Each student got pre-test } \\
& \text { score. } \\
\checkmark & \text { Each students had } \\
& \text { Google Site }\end{array}$ \\
\hline 2 & $\begin{array}{l}\text { Training on using } \\
\text { Google Site as English } \\
\text { Academic Diary }\end{array}$ & $\begin{array}{l}\text { Each student had Google } \\
\text { Site section for English } \\
\text { Academic Diary }\end{array}$ \\
\hline 4 & $\begin{array}{ll}\checkmark & \text { Post-test } \\
\checkmark & \text { Distributing } \\
& \text { questionnaire } \\
\text { perception toward the } \\
\text { use of Google Site as } \\
\text { online Academic Diary. }\end{array}$ & $\begin{array}{ll}\checkmark \quad \text { Each student got post- } \\
\text { test score. } \\
\checkmark \quad \text { Students delivered their } \\
\text { perception and evaluated } \\
\text { the training. }\end{array}$ \\
\hline
\end{tabular}




\section{RESULT AND DISCUSSION}

\section{Online Academic Diary Training Process}

The training was conducted for two months; February to March 2021. The activities were in two modes; online and offline. The online activity consisted of four meetings, and the offline activity took one meeting. Initially, students were introduced to Google Site; its use and features. The introduction to Google Site was conducted online. After that, students were given time to be able to create their own Google Site. The following were the images of training process conducted online and offline.
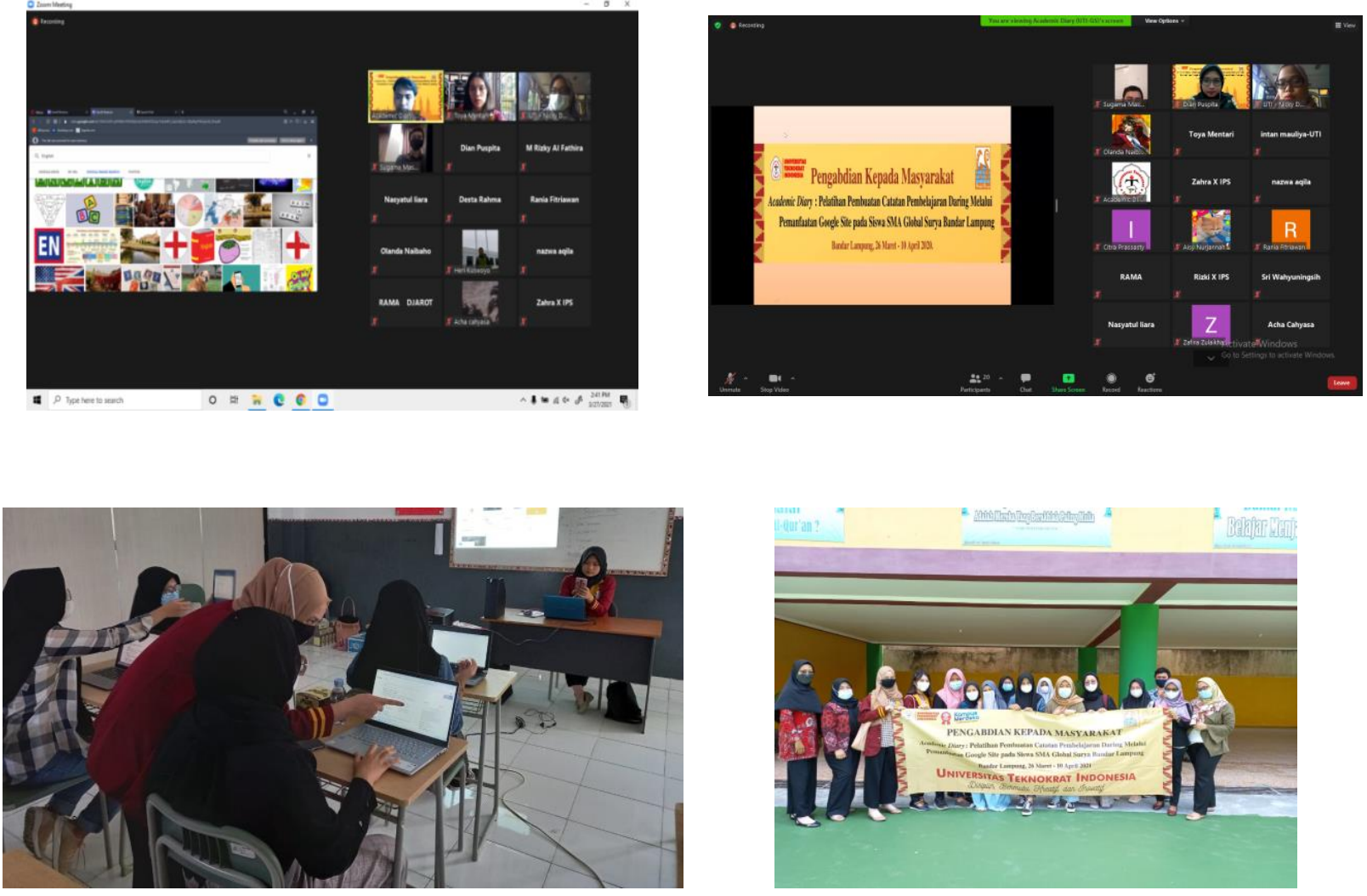

Figure 2. Online and Offline Training Process

The training was conducted and finished well even though during the pandemic era. The offline activities were following the Covid-19 procedures, and also under the consent of the school and students' parents. The objective of the training was also achieved, proven by the Google Site created by students which is used as online Academic Diary for English subject. The following picture is showing the example of student's Google Site.
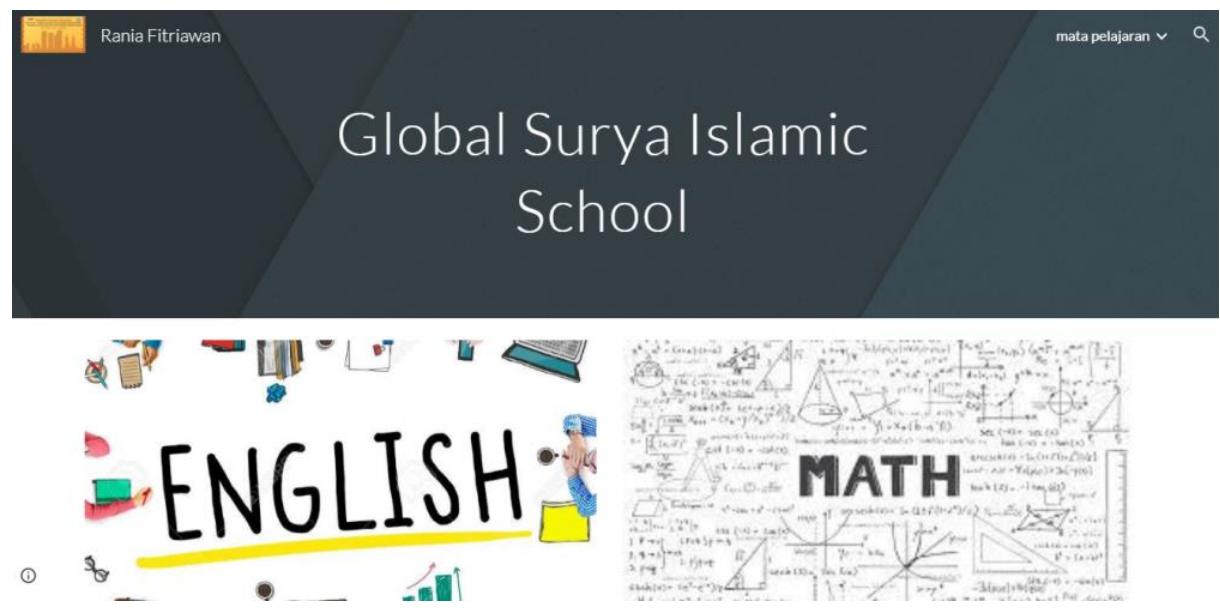
Figure 3. Student's English Academic Diary in Google Site

In the academic diary, students uploaded the English materials in some file types such as in pdf, ppt, or docs, obtained from their teacher, or from their own notes. Also, some videos and several exercises related to the topics were uploaded. This was done to organize their notes to be able to be easily accessed.

\section{Students' Perception toward the use of Google Site as Academic Diary}

The questionnaire was distributed at the end of the activity. 20 students filled out the questionnaire. This was aimed to find out students' perception toward the training process and the use of Google Site as online Academic Diary. There are 8 indicators in the questionnaire; Perceptions of Digital Technology, Perceptions of Previous Blogging Experience, Expectations of Blogging, Rhythm of Blogging - Writing, Rhythm of Blogging - Reading, The use of Google Site, The use of Google Site as Academic Diary, Perceived Learning. The following figure showed the result of the questionnaire.

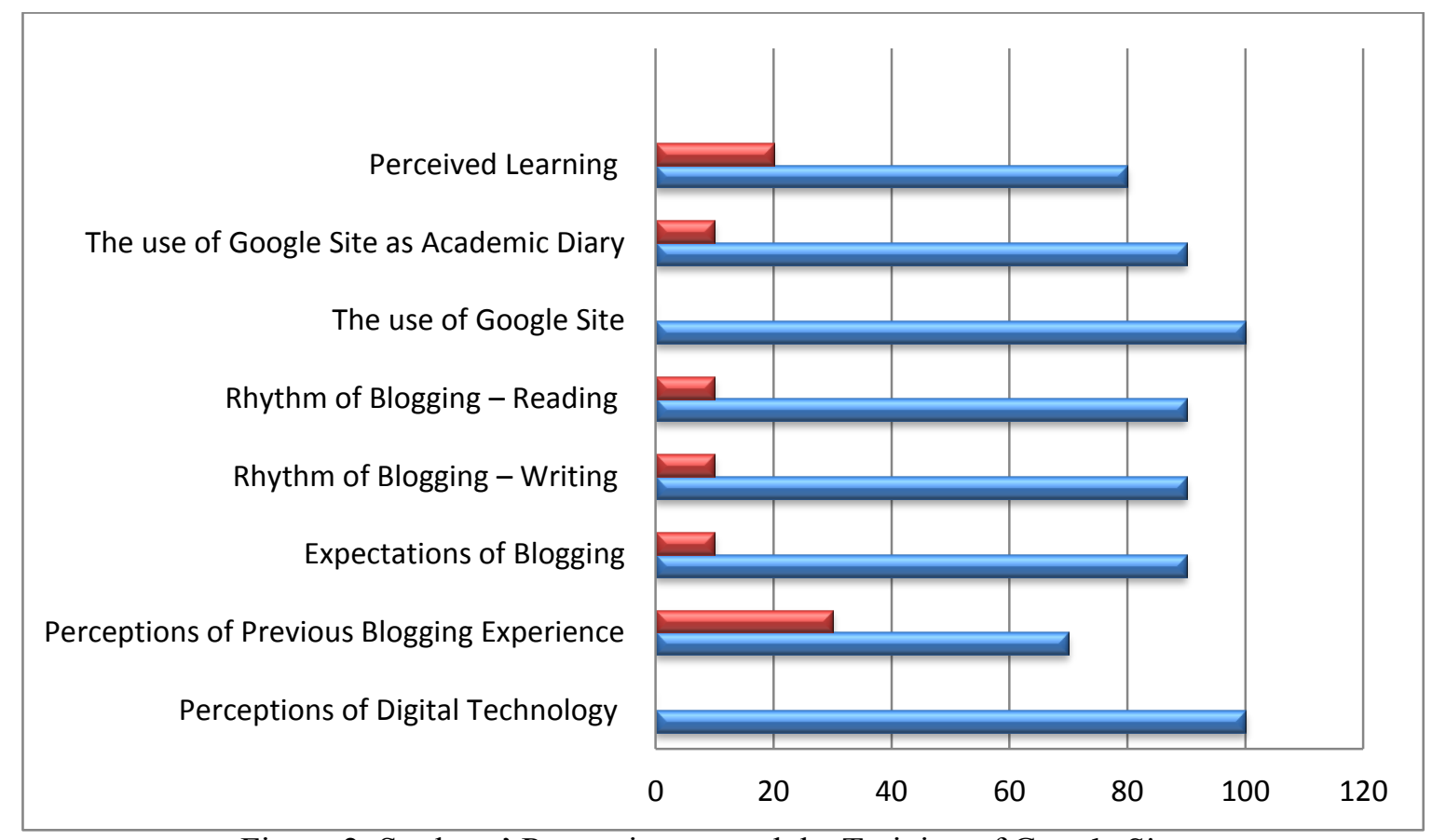

Figure 2. Students' Perception toward the Training of Google Site

Figure 2 showed that generally students got positive perception toward the result of training activities. There were two indicators which received $100 \%$ positive response namely Perception of Digital Technology and the use of Google Site. Perception of Digital Technology, students believe that internet has potential as a learning tool, and they can enhance their academic performance. In addition, in the use of Google Site, the agreed that Google Site has the right benefits to be used as academic supporting platform.

Also, the figure revealed that the majority of students gave a positive response to the training on the how to write and use of English notes using the Google Site. It means that this questionnaire data shows that students have a good understanding of the purpose of using these online notes to optimize online learning, starting from organizing and integrating online notes that have been made with information provided by the teacher or other information on the internet. 


\section{CONCLUSION}

To conclude, students' perception toward the use of Google Site as online Academic Diary for English subject was positive. Students got the better perception on digital use on learning, especially the one in Google Site. This is an innovative action which Students can continue uploading their Academic Diary in their English notes. Also it proved that technology is able to provide education access anytime and anywhere. Students can access their notes anytime and anywhere.

\section{ACKNOWLEDGEMENT}

The writers would like send the gratitude to Universitas Teknokrat Indonesia and LPPM Universitas Teknokrat Indonesia so this community service activity could run well. This community service is an Internal Grant from Universitas Teknokrat Indonesia with a Letter of Agreement on the Assignment of Community Service Implementation Number 020/UTI/LPPM/E.1.8/II/2021.

\section{REFERENCES}

Arumdani, I. M., Wasito, B., \& Sabandi, M. (2018). Pengaruh Pemanfaatan Situs Google Sebagai Sumber Belajar dan Motivasi Belajar Terhadap Prestasi Belajar Pada Mata Pelajaran Ekonomi Kelas XI di SMA Negeri 3 Surakarta. BISE: Jurnal Pendidikan Bisnis Dan Ekonomi, 4(2), 1-17.

Djusar, S., Fajrizal, \& Asril, E. (2021). Peningkatan Kemampuan Siswa Sman 16 Pekanbaru Dalam Pemanfaatan Situs Google Untuk Pembelajaran. J-COSCIS : Journal of Computer Science Community Service, 1(1), 31-36. https://doi.org/10.31849/jcoscis.v1i1.5686

Mandasari, B., \& Aminatun, D. (2019). Uncovering Students' Attitude toward Vlogging Activities in Improving Students' Speaking Ability. Premise: Journal of English Education, 8(2), 214. https://doi.org/10.24127/pj.v8i2.2241

Puspaningtyas, N. D., \& Dewi, P. S. (2020). Persepsi peserta didik terhadap pembelajaran berbasis daring. Jurnal Pembelajaran Matematika Inovatif (JPMI), 3(6), 703-712. https://doi.org/10.22460/jpmi.v3i6.703-712

Puspita, D., \& Amelia, D. (2020). Ted-Talk: a Supplement Material To Promote Students ' Autonomy in Listening. ELTIN Journal, 8, 91-102.

Puspita, D., Mandasari, B., \& Sari, K. (2021). Peningkatan Pengetahuan Penyusunan Soal Berbasis HOTS Pada Guru Bahasa Inggris SMA Negeri 1 Kotagajah. Abdi Kami, 4(1), $48-55$.

Setyawan, B. (2019). Pengembangan Media Google Site Dalam. Jurnal Nusantara of Research, $6,78-87$.

Susanthi, I. G. A. A. D. (2020). Kendala Dalam Belajar Bahasa Inggris Dan Cara Mengatasinya. Linguistic Comunity Service Journal, 1(2), 3.

Taufik, M., Sutrio, A. S., Sahidu, H., \& Hikmawati. (2018). Pelatihan Media Pembelajaran Berbasis Web Kepada Guru Ipa Smp Kota Mataram. Journal Pendidikan Dan Pengabdian Masyarakat, 1(1), 77-81.

Ulfa, M., \& Puspaningtyas, N. D. (2020). The Effectiveness of Blended Learning Using A Learning System in Network (SPADA) in Understanding of Mathematical Concept. Matematika Dan Pembelajaran, 8(1), 47-60. https://core.ac.uk/download/pdf/327234460.pdf

Wiramarta, K. (2021). Tantangan Pembelajaran Bahasa Inggris Pada Aspek Berbicara Pada Sekolah Pariwisata Dalam Masa Pandemi. 2(1), 1-11. 